\title{
Anticancer Activity of Solvent Extracts of Hexogonia glabra against Cervical Cancer Cell Lines
}

\author{
Swapan Kumar Ghosh*, Tapojyoti Sanyal, Tanmay Bera
}

\begin{abstract}
Objective: In this study, we aimed to harness some solvent extracts of one wild mushroom Hexagonia glabra and test their anti-cancer activity against cervical human cell lines, namelyHeLa, SiHa, and CaSki. Methods: It includes cell morphological study by microscope, nuclear morphology by DAPI staining under fluorescence microscopy, apoptosis assay by fluorescence technique, anti-proliferation by MTT assay and expression of apoptotic and anti-apoptotic genes by Western blotting and cell cycle analysis was done. Results: The selected cervical cancer cells were treated separately with $150 \mu \mathrm{g} / \mathrm{mL}$ of three extracts, namely of ethanolic (EE), ethyl acetate (EAE), and water extract (WE) and exhibited features like round, shrink and dead. All extracts caused apoptosis in cell lines and EE had the highest effect in this regard. The percentages of apoptotic cells in HeLa, SiHa and CaSki, at the same concentration of EE were 79.23, 75.42, and $76.36 \%$ respectively. Cytotoxicity assay showed that all three extracts $(50-250 \mu \mathrm{g} / \mathrm{mL})$ were potent for inhibition of cell growth of three cell lines and again EE had the highest effect. The percentages of cell growth inhibition in HeLa, $\mathrm{SiHa}$, and CaSki cells treated with EE at $24 \mathrm{~h}$ at $50 \mu \mathrm{g} / \mathrm{mL}$ were $45.79 \pm 4.11,41.66 \pm 4.03$, and $36.72 \pm 2.67$, while they were $74.23 \pm 7.45,62.31 \pm 5.97$, and $54.23 \pm 5.04$ at $150 \mu \mathrm{g} / \mathrm{mL}$ concentration. At $250 \mu \mathrm{g} / \mathrm{mL}$ concentration, the percentages of cell growth inhibition were $94.25 \pm 8.11,90.02 \pm 8.67$, and $85.43 \pm 6.21$, respectively. The expression of apoptotic gene (Caspase 3, 9) and tumor guard gene (p53), as their proteins in Western blotting increased . However, anti-apoptotic $B c L 2$ gene of all cell lines was decreased following treatment with extracts. In addition, the cell cycle analysis (CaSki cell) showed that treatment (EE) arrested at G2/M check point cell cycle. Conclusion: All extracts of this mushroom were active in arresting growth of three cell lines and EE had the highest effect, indicating that this mushroom can be a valuable source of anticancer agents.
\end{abstract}

Keywords: Human cancer cell line- mushroom- apoptosis- cytotoxicity- MTT assay

Asian Pac J Cancer Prev, 21 (7), 1977-1986

\section{Introduction}

Cancer is now one of the most complex killer diseases among human beings. Hurdles and hopes for cancer treatment are going on, but scientists search the new natural compound that can be applied as an anticancer remedy (Hunt, 2002). Searching for natural sources to find novel bioactive anticancer compounds may provide next generation of drugs (Liu et al., 2010; Lindequist et al., 2010; Xu et al., 2011; Aly et al., 2011). Mushrooms are macro-fungi whose so-called fruit bodies are seen under naked eyes. Nowadays, scientists have paid much attention to mushrooms in cancer management because they have hundreds of novel natural constituents with biological properties with lower toxic side effects and even lower cost (Lee et al., 2014; Shavit et al., 2009). In addition, mushroom extracts can act as immunomodulatory factors in the management of cancer patients (Ghosh and Chakrabarty, 2018). Lucas et al., (1957) for the first time showed that mushrooms had anticancer property. After intensive research, some anticancer drugs, Lentinan from fruiting bodies of Lentinus edodus, Krestin from cultured mycelium of Trametes versicolor, and Schizophyllan from fruit body of Schizophyllum commune, were introduced for cancer management (Mizuno, 1999; Wasser, 2002; Mo, 2004). Some mushroom products like Grifolan from Grifola frondosa exhibit anti cancer activity against breast, gastrointestinal, liver, and lung cancers (Poucheret et al., 2006) by activating macrophage which triggers cytokine secretion. SSG, a homoglucan from Sclerotinia sclerotiorum, triggers the development of TH1 cells via the IL-12 pathway. It is also isolated from Sparassis crispa and usually enhances the hematopoietic response (Moradali et al., 2007). Some $\beta$-glucans from medicinal mushrooms are responsible to activate both cell-mediated and humoral immunity by triggering different immune cells ( $\mathrm{T}$-cells, B- cells, macrophage, etc), hence rejecting tumor cells (Ladanyi et al., 1993; Kim et al., 1996; Kurashige et al., 1997; Brown and Gordon, 2003). The activated macrophages also secrete cytokines that 
prime natural killer (NK) cells and T lymphocytes, both of which are cytotoxic to tumor cells (Prestwich et al., 2008). There are more than 14,000 mushrooms out of 5.1 million estimated fungi (Blackwell, 2011), among which near about 700 exhibit medicinal properties (Wasser, 2011). In India, described mushroom species are 850 (Deshmukh, 2004; Manoharachary et al., 2005). Although the rate of application of fungi in different sectors has been increased exponentially throughout the world, near about $90 \%$ of fungal species are not yet screened in medical application like anticancer drug development. Among edible mushrooms, members of Agaricus are produced maximum, whilst from the non-edible medicinal mushroom Ganoderma are produced and used maximum globally. Many members of the Polyporaceae family have been now selected as the next candidate producers of possible valuable medicines (Mizuno, 1995). In India particularly in West Bengal, mushrooms are abundant but systematical screening of those as anti tumor or cancer has not been investigated by any one yet. On the other hand, every year in India, 122,844 women are diagnosed with cervical cancer, and 67,477 die from this disease (ICO, 2014; Sreedevi et al., 2015). The present treatments for cancer include chemotherapy, surgery, and radiation. All of these treatment approaches are associated with some complications. For instance, chemotherapeutic drugs are becoming narrow potential; on the other hand, patients are becoming resistant to these drugs (Ghosh, 2018). Under such situation, it is highly essential to search for new natural anticancer compounds, which are target specific and immune- enhancer. The screening of different mushroom extracts and isolation of different natural compounds and their targeted anticancer effects with immune enhancing property are need of hour. In this study, we tested wild Hexogonia glabra mushroom extracts, such as ethanolic (EE), ethyl acetate (EAE), and water extract (WE), as anticancer agents against cervical cell lines (HeLa, SiHa and CaSki).

\section{Materials and Methods}

\section{Mushroom collection}

Fruiting bodies of wild mushroom, Hexagonia glabra (P. Beauv.) Ryvarden (Family: Polyporaceae), were collected in September 2018 from different wooden logs from various zones of south Twenty Four Parganas district, India. The samples were sent to laboratory, and their identification was confirmed by consulting with the published keys (Ryvarden, 1999; Watling, 1973; Pacioni and Lincoff, 1981; Moser, 1983).

\section{Extraction}

The fruiting bodies of the wild mushroom (Hexagonia glabra) were washed in tap water and then distilled water to remove impurities. Hence, they were air dried in oven at $50^{\circ} \mathrm{C}$ for $48 \mathrm{~h}$, chopped into pieces, and grinded into powder using mixer grinder. Briefly, $15 \mathrm{~g}$ of dried mushroom powder was dipped in $150 \mathrm{~mL}$ of $90 \%$ ethanol in glass bottles with tightly fitted cap, under shaking condition at room temperature for 3 days. The same procedure was followed for ethyl acetate extract
(EAE). In case of water extract (WE), mushroom power was dipped in boiling water for $30 \mathrm{~min}$. All extracts were filtered through Whatman No. 4 followed by Whatman No.1 filter papers, and then filtrates were collected. The solvents from each filtrate of extracts were removed using a rotary vacuum evaporator at $40^{\circ} \mathrm{C}$, and hence the extract was lyophilized to dry powder. The powder of extracts (EE, EAE, and WE) was weighed and kept in airtight condition in refrigerator at $4^{\circ} \mathrm{C}$ for further use. Extracts used for in vitro assays were dissolved in plain RPMI 1640 medium and passed through a $0.22 \mu \mathrm{m}$ Millipore filter for sterilization. The prepared extract was further diluted with plain RPMI 1640 medium in certain concentrations just prior to use.

\section{Cell culture}

Three human cervical cancer cell lines, namely HeLa, $\mathrm{SiHa}$, and CaSki, were purchased from NCCS, Pune, India. They were cultured separately in Dulbecco's Modified Eagle media (DMEM) supplemented with L-Glutamine (Company), 10\% v/v fetal bovine serum (company), $100 \mu \mathrm{g} / \mathrm{mL}$ streptomycin (Invitrogen), and $250 \mathrm{IU} / \mathrm{mL}$ penicillin (Invitrogen) in 75 square $\mathrm{mm}$ tissue culture flasks at $37^{\circ} \mathrm{C}$ in a humidified atmosphere of $5 \% \mathrm{CO}_{2}$ to the $80-90 \%$ confluence (Freshney, 2015).

Morphological examination of cancer cells after treatment with EE, EAE, and WE Cell morphology study by phase contrast/ bright field microscopy

Each cancer cell line was grown in 60-mm tissue culture dish and treated with each extract separately at $150 \mu \mathrm{g} / \mathrm{mL}$ of extract concentration for $24 \mathrm{~h}$. Cells were examined under phase contrast/bright field microscopy, and photographs were taken using a Magna-Fire digital camera for analysis.

\section{Nuclear morphology by DAPI staining under inverted} fluorescent microscope

DAPI (4', 6-Diamidino-2-phenylindole) staining was done to observe the treated $(150 \mu \mathrm{g} / \mathrm{mL}$ of extract power) cells' nuclear morphology. The HeLa, SiHa, and CaSki were washed with cold PBS and fixed with $3.7 \%$ (w/v) para-formaldehyde in PBS for $10 \mathrm{~min}$ at room temperature. After permeabilization, the cells were stained with a DAPI $(10 \mu \mathrm{g} / \mathrm{mL})$ solution at $37^{\circ} \mathrm{C}$ for $30 \mathrm{~min}$. The cells were washed with PBS and were examined under an inverted fluorescent microscope (Olympus, Tokyo, Japan), and photographs were taken using a Magna-Fire digital camera (Optotronics, Goleta, CA, USA) for analysis.

\section{Evaluation of apoptosis by DAPI staining under inverted fluorescent microscope}

Apoptosis was evaluated by morphological changes in the nuclear structure of all three treated $(150 \mu \mathrm{g} / \mathrm{mL})$ cell lines stained with DAPI comparing with control set. The apoptotic cells were analyzed and counted under an inverted fluorescent microscope in each experiment, and at least five optical fields were counted in each of them containing a total of 200 cells. 
The percentage of apoptotic cells was calculated by the following formula:

Percentage of apoptotic cells $=$ [number of apoptotic cells / total cells counted (200 usually)] $\times 100 \%$.

\section{Cell proliferation or cytotoxicity assay}

The effects of each mushroom extract on cell proliferation of HeLa, SiHa, and CaSki cell lines were evaluated by using Dimethyl thiazolyl tetrazolium bromide (MTT) assay (Sigma, USA) and in accordance with Mosmann method (Mosmann, 1983) and by implementing some modifications. Briefly, $10 \times 10^{3}$ cells per well of 96-well culture plate were seeded with fresh DMEM medium, containing 10\% FBS and antibiotics, overnight to reach $80 \%$ confluency. Then, the culture was washed with $10 \%$ PBS, treated at different concentrations $(0,50,100,150,200$, and $250 \mu \mathrm{g} / \mathrm{mL}$ of each extract dissolved in DMEM), and incubated at $37^{\circ} \mathrm{C}$ in $5 \%$ of $\mathrm{CO}_{2}$ and $95 \%$ of air. After 24,48 , and $72 \mathrm{~h}$ treatment, cells were washed with PBS, $100 \mu \mathrm{L}$ of $0.5 \%$ MTT solution (dissolved in RPMI 1640) was added to each well, and cultures were further incubated for $3 \mathrm{~h}$. After discarding the media, $100 \mu \mathrm{L}$ of DMSO was added for dissolving the crystals. The plate was read by using micro plate reader (Bio-Rad) at $570 \mathrm{~nm}$ absorbance. For the normal human lymphocytes, which are in suspension, the cytotoxicity was evaluated using the water-soluble MTS (Vorauer et al., 1996) dye.

Growth inhibition rate was determined by the following formula:

Growth inhibition $=[1-\mathrm{A} 570 \mathrm{~nm}$ of treated cells $/ \mathrm{A}$ $570 \mathrm{~nm}$ of control cells] $\times 100 \%$

The concentration which led to a $50 \%$ killing $\left(\mathrm{IC}_{50}\right)$ was calculated by plotting a dose response graph of the cytotoxicity values obtained using the formula given below:

$\%$ Cell cytotoxicity $=100-[($ A control $-\mathrm{A}$ test $/ \mathrm{A}$ control) $\times 100]$

Data points represent the mean $\pm \mathrm{SD}$ in one experiment repeated at least thrice.

\section{Western blot analysis for study of gene expression}

Each cancer cell line $\left(2 \times 10^{5}\right)$ was treated with $150 \mu \mathrm{g} /$ $\mathrm{mL}$ of each extract separately for $24 \mathrm{~h}$. After treatment, cells were lysed with RIPA buffer (Abcam). The effect of treatment on the expression of certain genes as proteins, such as p53, and on apoptotic proteins, such as Bcl-2, caspase-3, and caspase-9 (Santacruze Biotechnology, USA), were measured. Proteins were detected by incubation with the corresponding primary antibodies, and antibodies followed by blotting with the HRP-conjugated secondary antibody. The blots were then detected using Luminol (Bio-Rad), and intensity of bands of each protein was measured by Image $\mathrm{J}$.

\section{Cell cycle analysis}

CaSki cells $\left(7.5 \times 10^{5}\right)$ were seeded in $100 \mathrm{~mm}$ dishes, and cultured in DMEM containing 10\% FBS for $24 \mathrm{~h}$. Then, cells were incubated with EE (50 and $150 \mu \mathrm{g}$ / $\mathrm{ml})$ and positive control Cisplastin $(50 \mu \mathrm{g} / \mathrm{ml})$ separately
Anticancer Effect of Hexogonia glabra against Cervical Cancer at $37^{\circ} \mathrm{C}$ and $5 \% \mathrm{CO}_{2}$ for $24 \mathrm{~h}$, where DMEM used as vehicle control. After incubation, the cells were harvested, washed with Dulbecco's PBS containing 1\% FBS, and re-suspended in $50 \mu \mathrm{g} / \mathrm{ml}$ propidium iodide (PI). Samples were analyzed on a fluorescence-activated cell sorting (FACS Calibur BD Bioscience, USA).The fractions of cells in the various phases of the cell cycle $(\mathrm{G} 0 / \mathrm{G} 1, \mathrm{~S}$, and $\mathrm{G} 2 / \mathrm{M}$ ) were shown as a percentage of the total cells analyzed.

\section{Results}

\section{Yield of extracts}

The yields of EE, EAE, and WE of P. glabra (Figure 1) were 7.79, 2.21, and 5.46\% (W/W), respectively.

\section{Cell morphological study of all three cell lines under phase contrast microscopy}

Figure 1 showes that HeLa cells treated with 150 $\mu \mathrm{g} / \mathrm{mL}$ of EE resulted in more round, shrunken, and membrane blabbing. The dead cells and cell debris were also observed. The cells treated with $150 \mu \mathrm{g} / \mathrm{mL}$ of EAE and WE, separately, were similar to fate of HeLa cells. Other two cell lines ( $\mathrm{SiHa}$ and CaSki), when exposed to earlier concentration of these extracts at $24 \mathrm{~h}$, showed the same trends. All three types of cancer cells treated with Adriamycin (positive control) became round shape, while many cells were dead (Figure 1).

Nuclear morphological study of all three cell lines under florescence microscopy

Nuclei of the control/ untreated HeLa, SiHa, and CaSkilcells appeared normal taking light blue color and were round and homogeneous, while nuclei which were treated with EE, EAE, and WE, separately, were condensed and in few cases were irregular and fragmented (Figure 2). It was revealed that all four extracts were effective on inducing apoptosis of all three cell lines.

\section{Evaluation of apoptosis by DAPI staining under inverted fluorescent microscope}

The percentages of apoptotic cells of $\mathrm{HeLa}$, SiHa, and CaSki were 79.23, 75.42, and $76.36 \%$, respectively, at $150 \mu \mathrm{g} / \mathrm{mL}$ concentrations of EE. At positive control (Adriamycin), the percentages were 88.34, 86.09, and $87.51 \%$, respectively (Figure 3 ). The percentages of apoptotic cells of HeLa, SiHa and CaSki at $150 \mu \mathrm{g} / \mathrm{mL}$ concentrations of EAE were 55.67, 37.12, and 51.07\%, respectively. The percentages were $65.32,46.12$, and $51.78 \%$, respectively, at $150 \mu \mathrm{g} / \mathrm{mL}$ concentrations of WE. It indicated that exposure of all three cell lines to these mushroom extracts (EE, EAE and WE) for $24 \mathrm{~h}$ resulted in apoptosis (Figure 3).

\section{Anti proliferative/cytotoxicity effect of mushroom extracts against HeLa, SiHa, and CaSki cell lines based on MMT assay}

We investigated the effect of each of three extracts on cell proliferation of three cell lines. According to Table 1, the proliferation of all cell types was reduced gradually as dosage of EE increased gradually from 50 

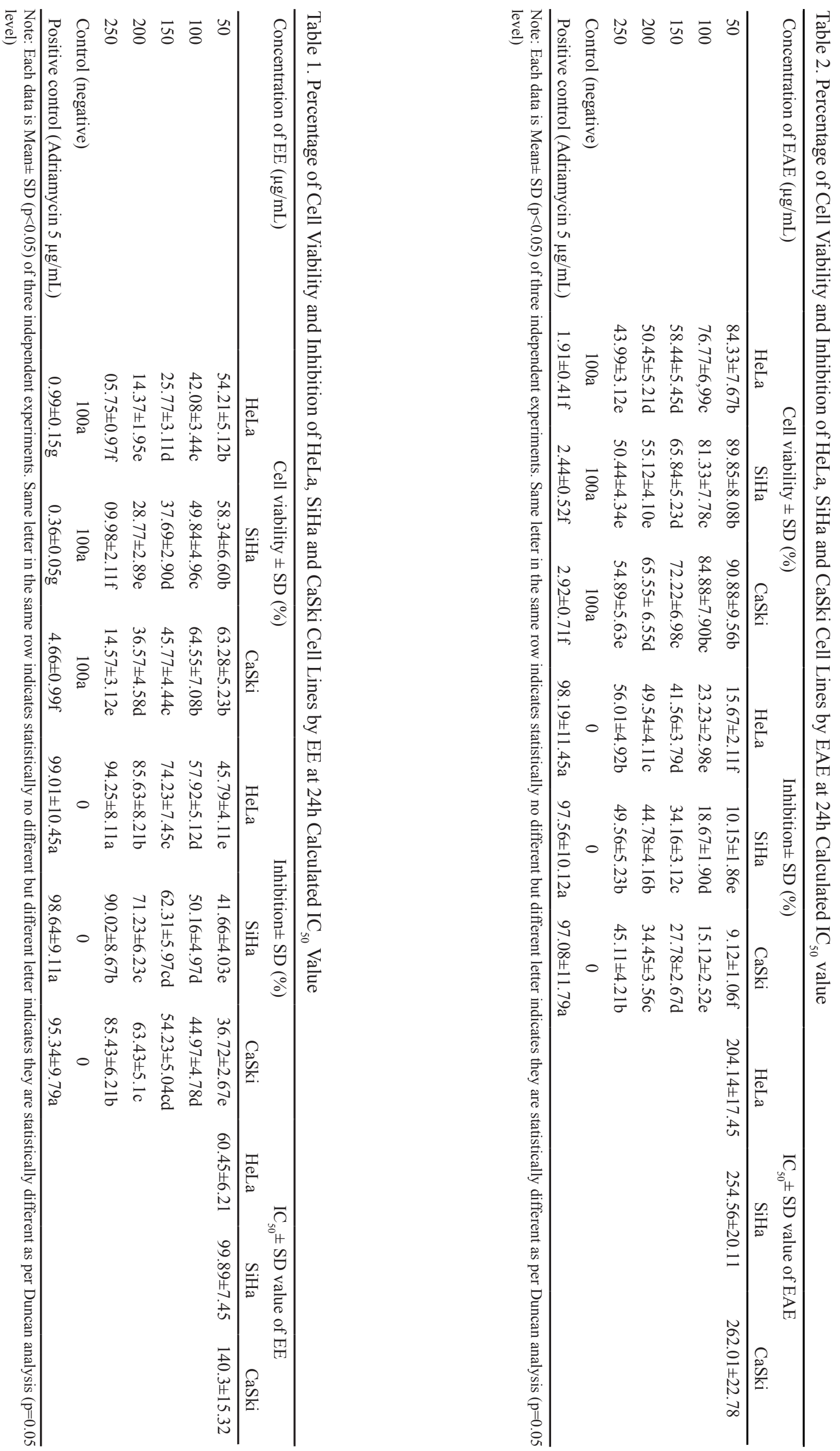

1980 Asian Pacific Journal of Cancer Prevention, Vol 21 


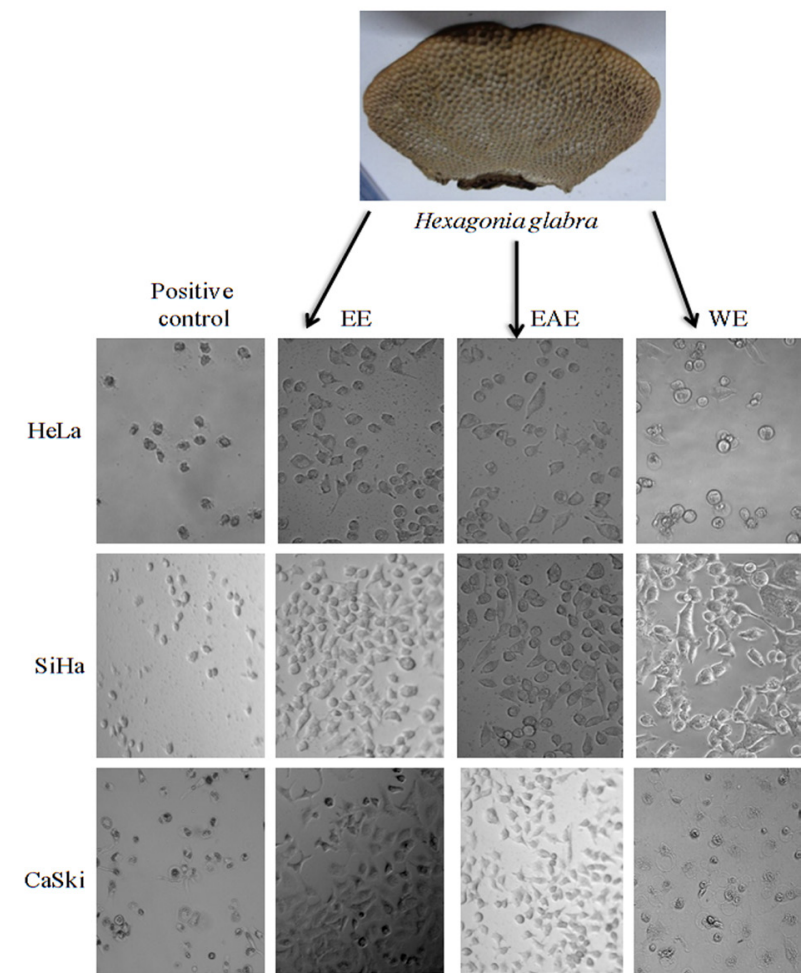

Figure 1. Morphological Changes of Human Cancer Cell Lines Treated with EE, EAE, WE $(150 \mu \mathrm{g} / \mathrm{mL})$ and Negative Control under Phase Contrast Microscope at $24 \mathrm{~h}$. HeLa, SiHa and CaSki cells have no changes in Negative Control; but treated cells are round, degenerated and dead

to $250 \mu \mathrm{g} / \mathrm{mL}$. The percentages of cell growth inhibition in $\mathrm{HeLa}$, SiHa, and CaSki cells treated with $\mathrm{EE}$ at 24 $\mathrm{h}$ at $50 \mu \mathrm{g} / \mathrm{mL}$ (the lowest dosage) were $45.79 \pm 4.11$, $41.66 \pm 4.03$, and $36.72 \pm 2.67$, respectively. At $150 \mu \mathrm{g} / \mathrm{mL}$ (the moderate dosage), the percentages were $74.23 \pm 7.45$, $62.31 \pm 5.97$, and $54.23 \pm 5.04$. At $250 \mu \mathrm{g} / \mathrm{mL}$ (the highest dose), the percentages were $94.25 \pm 8.11,90.02 \pm 8.67$, and $85.43 \pm 6.21$, respectively. The positive control (Adriamycin $5 \mu \mathrm{g} / \mathrm{mL}$ ) inhibited all three cell lines by $99.01 \pm 10.45,98.64 \pm 9.11$, and $95.34 \pm 9.79 \%$, respectively. Data from Table 2 showed that the proliferation of all cell types were reduced gradually as dosage of EAE increased $(50-250 \mu \mathrm{g} / \mathrm{mL})$. The percentages of cell growth inhibition in $\mathrm{HeLa}, \mathrm{SiHa}$, and CaSki cells treated with EAE at $24 \mathrm{~h}$ at $50 \mu \mathrm{g} / \mathrm{mL}$ (the lowest dosage) were $15.67 \pm 2.11,10.15 \pm 1.86$, and $9.12 \pm 1.06$, while at 150 $\mu \mathrm{g} / \mathrm{mL}$ (the moderate dosage), the percentages were $41.56 \pm 3.79,34.16 \pm 3.12$, and $27.78 \pm 2.67$, respectively. Regarding $250 \mu \mathrm{g} / \mathrm{mL}$ dosage (the highest dosage), the percentages of cell growth inhibition in studies cells were $56.01 \pm 4.92,49.56 \pm 5.23$, and $45.11 \pm 4.21$, respectively (Table 2). As it is clear from Table 3, the percentages of cell growth inhibition in $\mathrm{HeLa}$, SiHa, and CaSki cells treated with WE at $24 \mathrm{~h}$ at $50 \mu \mathrm{g} / \mathrm{mL}$ (the lowest dosage) were $21.81 \pm 2.34,18.43 \pm 1.75$, and $25.88 \pm 2.59$, while at $150 \mu \mathrm{g} / \mathrm{mL}$ (the moderate dosage) were $38.56 \pm 3.78$, $34.19 \pm 3.90$, and $49.23 \pm 4.15$. At $250 \mu \mathrm{g} / \mathrm{mL}$ dosage (the highest dosage), the percentages were $67.90 \pm 6.01$, $51.23 \pm 5.56$, and $75.56 \pm 6.45$, respectively (Table 3 ). It was noted that HeLa was more sensitive to EE and EAE, 


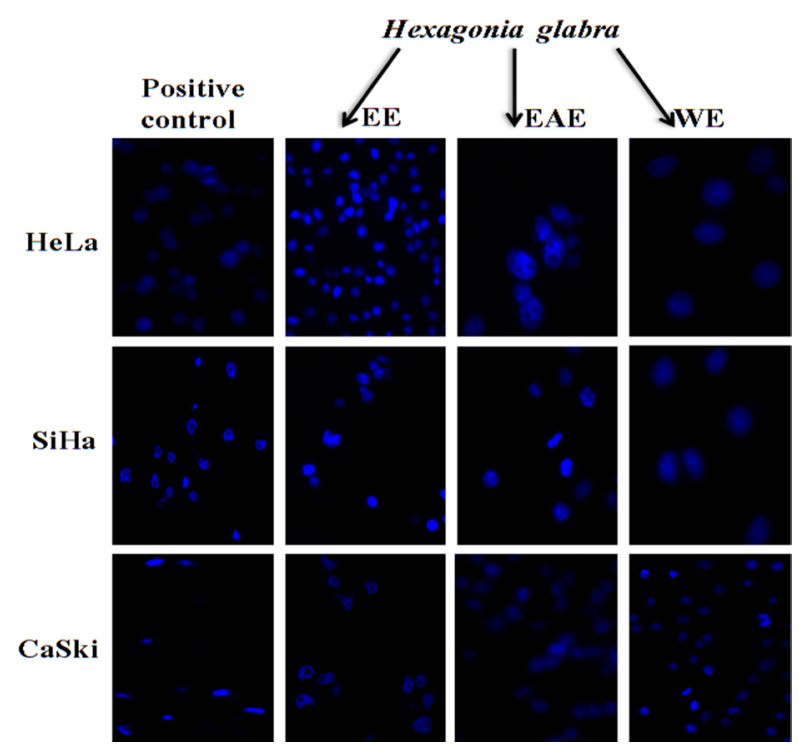

Figure 2. Nuclear Morphology of Human Cancer Cell Lines Treated with EE, EAE, WE $(150 \mu \mathrm{g} / \mathrm{mL})$, Negative Control under Inverted Fluorescence Microscope at 24 h. HeLa, SiHa and CaSki nuclei are condensed, highly fluoresced and lobed under exposure of mushroom extracts and Negative Control exhibited no nuclear changes

while CaSki cell line was more sensitive to WE than other two cell lines (Tables 1-3). The percentages of cell growth inhibition in all treated $(150 \mu \mathrm{g} / \mathrm{mL}$ of EE, EAE, WE) cell lines were increased gradually when incubation time was increased from 24 to $72 \mathrm{~h}$ (Data not shown). $\mathrm{IC}_{50}$ values of $\mathrm{EE}$ against $\mathrm{HeLa}, \mathrm{SiHa}$, and CaSki were $60.45 \pm 6.21$, $99.89 \pm 7.45$, and $140.32 \pm 15.32 \mu \mathrm{g} / \mathrm{mL}$, respectively (Table 1). $\mathrm{IC}_{50}$ values of of EAE against these cell lines were $204.14 \pm 17.45,254.56 \pm 20.11$, and $262.01 \pm 22.78$, respectively (Table 2). IC50 values of of WE against these cell lines were $220.34 \pm 17.23,248.21 \pm 19.67$, and $152.66 \pm 11.44$, respectively (Table 3 ). All these extracts at the highest dosage $(500 \mu \mathrm{g} / \mathrm{mL})$ showed no cytotoxicity against the normal human lymphocytes up to $72 \mathrm{~h}$ (Data not shown).

Study of induction of apoptosis using gene expression in Western blotting assay

We found that treatment with EE, EAE, and WE at the concentration of $150 \mu \mathrm{g} / \mathrm{mL}$ decreased $B c L 2$ gene expression (Figure 4), while increased the expression of apoptosis genes, namely caspase 3 and caspase 9 in all three cell lines in vitro. Moreover, gene p53 of cell lines was up-regulated by EE, EAE, and WE (Figure 3). Comparative analysis among these three extracts for their ability to upregulate caspase 3, 9 and $p 53$ genes and down regulate $B C L 2$ genes in all three cancer cell lines, it was reflected that EE extract was best followed by WE and EAE respectively (Figure 4).

\section{Cell cycle arrest by EE extract}

The cell cycle distribution of CaSki cells was subsequently investigated using flow cytometry with the PI staining method. Based on Figure 5, the percentage of cells distributed in the G2/M phase of the cycle was $16.11 \%$ for the negative control (DMEM vehicle) (Figure $5 \mathrm{~A}$ ), and it was $19.55 \%$ in case of positive control (cisplastin $50 \mu \mathrm{g} / \mathrm{ml}$ ). The percentage of cells distribution in $\mathrm{G} 0 / \mathrm{G} 1$ was $54.67 \%$ (Figure $5 \mathrm{~B}$ ). Upon treatment with $\mathrm{EE}$ at concentrations of 50 and $150 \mu \mathrm{g} / \mathrm{ml}$, the percentages of cells distributed in the $\mathrm{G} 2 / \mathrm{M}$ phase increased gradually to $18.18 \%$ and $20.21 \%$ (Figure 5C, 5D), respectively. Treatment of the cells with EE at 50 and $150 \mu \mathrm{g} / \mathrm{ml}$ concentrations also led to a gradual decrease in the cell distribution at the G0/G1 and S phases compared with the negative control.

\section{Discussion}

Earlier occurrence and distribution of Hexagonia speciosa were recorded in China (Zhao, 1998), but there remains a lacuna in proper record of distribution of H. glabra in China and India as well. Its collection from fallen logs in 24-Parganas district of West Bengal, India was tentatively first place where it was collected

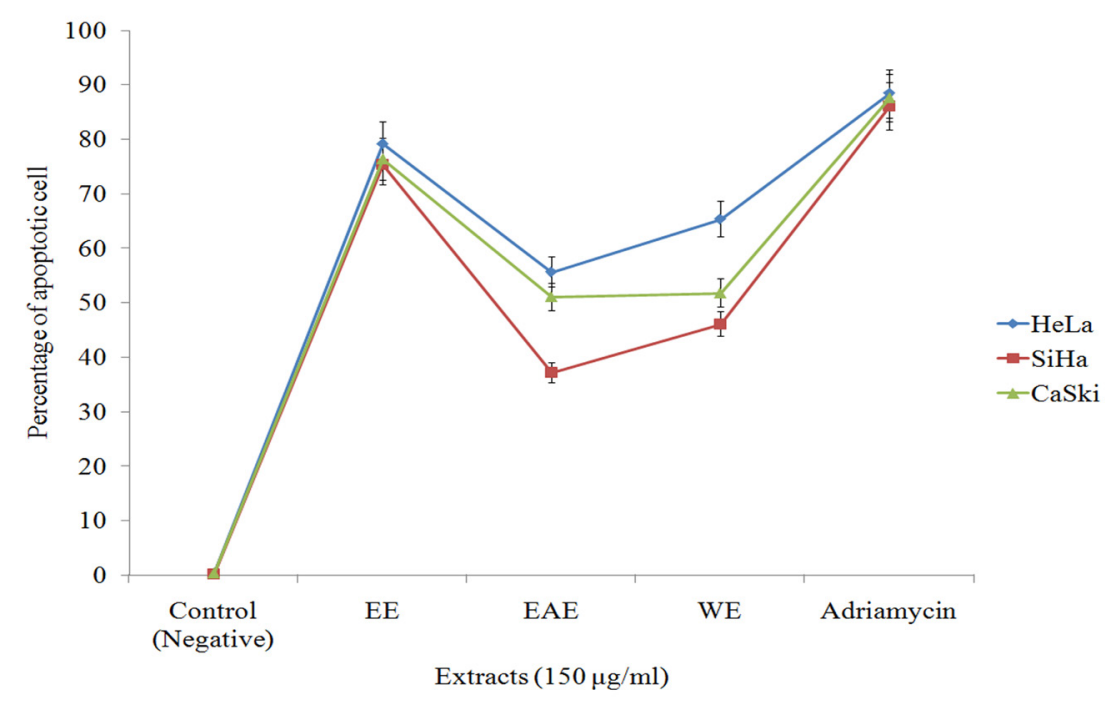

Figure 3. Effect of Mushroom Extracts (EE, EAE and WE) on the Rate of Apoptosis of Cervical Cancer Cell Lines (HeLa, SiHa and CaSki) Compared with Positive and Negative Control. X-axis denotes different mushroom extracts $(150 \mu \mathrm{g} / \mathrm{mL}$ concentration) and Y-axis denotes percentage of apoptotic cells. Standard error $(\mathrm{SE} \pm)$ bar inserted $(\mathrm{p}<0.05)$ 
B

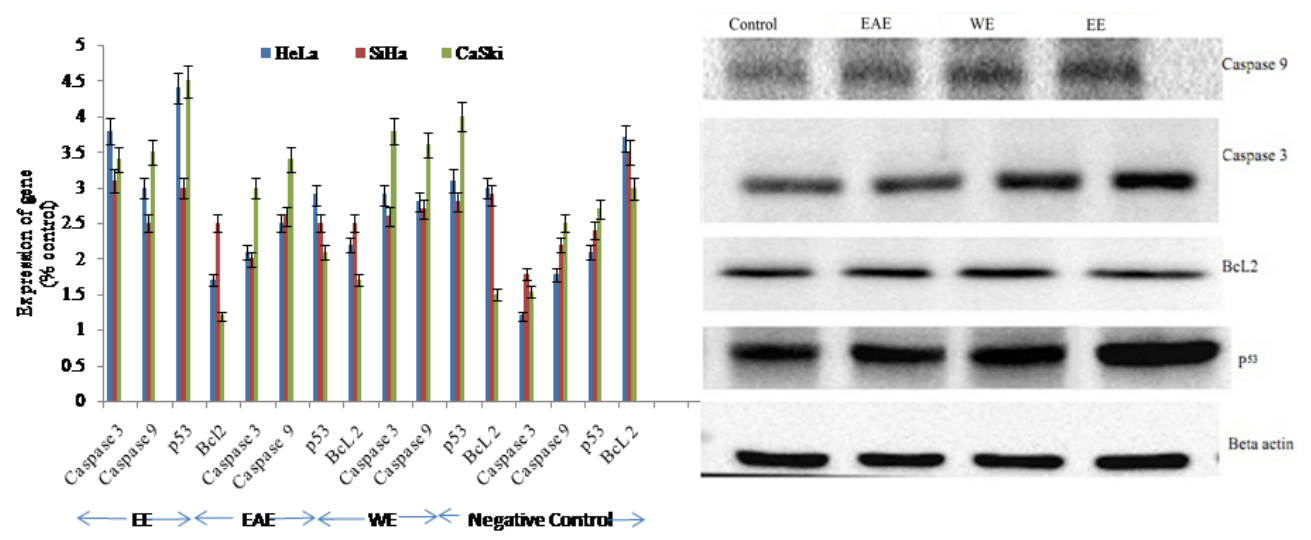

Figure 4. Expression of Genes Analyzed by Western Blotting Assay of the HeLa. SiHa nad CaSki cells treated by EE, EAE, WE and compared with Negative Control. A. The intensity of protein bands of expressed genes measured by Image J software. Standard error ( $\mathrm{SE} \pm$ ) bar inserted $(\mathrm{p}<0.05)$, B. Bands of proteins of CaSki cells in Western blotting after treatment with EE, EAE and WE $(150 \mu \mathrm{g} / \mathrm{mL}$ in each).

and yield of EE, EAE and WE of Hexagonia glabra in our experiment were taken but there are no reports of such yields earlier, yet. The isolation and structure determination of a series of oxygenated cyclohexanoids were performed by Jiang et al., (2009) from Hexagonia speciosa. They include speciosins, 5H-furan-2-one me-tabolite, 5'-O-acetylaporpinone A, and aporpinone A. Out of these compounds, speciosin B exhibited cytotoxicity against some cancer cell lines. $\mathrm{IC}_{50}$ values range from 0.23-3.30 $\mu \mathrm{M}$ (Jiang et al., 2009; Jiang et al., 2011). Silva et al., (2009) first reported antitumor activity of methanolic extract (ME) of the Hexagonia papyraceae
A

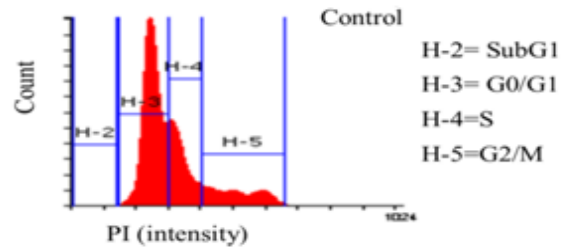

B

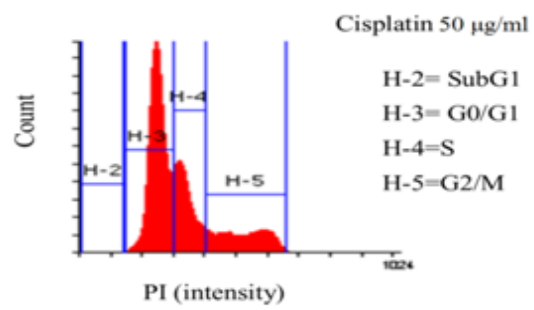

C

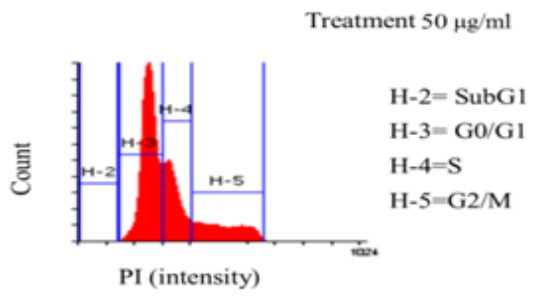

Treatment $150 \mu \mathrm{g} / \mathrm{ml}$

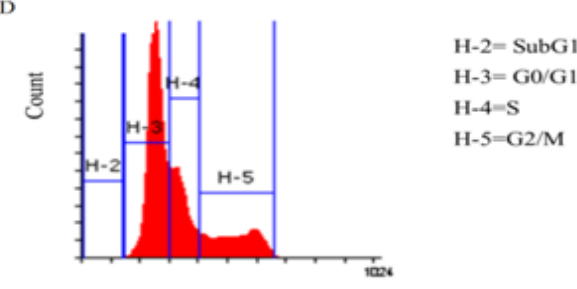

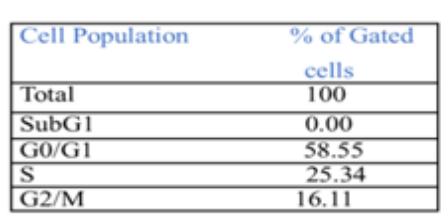

\begin{tabular}{|lc|}
\hline Cell Population & $\begin{array}{c}\% \text { of Gated } \\
\text { cells }\end{array}$ \\
\hline Total & 100 \\
\hline SubG1 & 0.00 \\
\hline G0/G1 & 54.67 \\
\hline S & 24.79 \\
\hline G2/M & 19.55 \\
\hline
\end{tabular}

\begin{tabular}{|lc|}
\hline Cell Population & $\begin{array}{c}\% \text { of Gated } \\
\text { cells }\end{array}$ \\
\hline Total & 100 \\
\hline SubG1 & 0.00 \\
\hline G0/G1 & 55.06 \\
\hline S & 26.76 \\
\hline G2/M & 18.18 \\
\hline
\end{tabular}

\begin{tabular}{|ll|}
\hline Cell Population & $\begin{array}{c}\% \text { of } \\
\text { Gated cells }\end{array}$ \\
\hline Total & 100 \\
\hline SubG1 & 0.00 \\
\hline G0/G1 & 55.63 \\
\hline S & 24.16 \\
\hline G2/M & 20.21 \\
\hline
\end{tabular}

Figure 5. Cell Cycle Analysis of CaSki by Flow Cytometry A. Vehicle (Negative) control; B. Positive control (Cisplastin $50 \mu \mathrm{g} / \mathrm{mL}$ ); C. Treatment (EE, $50 \mu \mathrm{g} / \mathrm{mL}$ ); D. Treatment (EE, $150 \mu \mathrm{g} / \mathrm{mL}$ ). 
against K562 (Human chronic myeloid leukemia cell) and Daudi (human Burkitt's lymphoma cell). ME inhibited more than $60 \%$ of the proliferation of both K562 and Daudi cells. The $\mathrm{IC}_{50}$ value against K562 was $39.1 \mu \mathrm{g} / \mathrm{mL}$. Literature review indicated that anticancer effect of solvent extract of H. glabra is not tested against any cancer cell line or in animal model by any workers . However, different solvent extracts of other mushrooms have been applied on several cancer cell lines. Laetiporus sulphureus, the saprophytic wild, cultivated polypore mushroom and weak parasite of plant, the ethanol extract of it also exhibited anti-proliferative activity against three carcinoma cell lines HeLa, HCT 116 and MCF-7 (Younis et al., 2019). The effects of ethanol extracts from G. frondosa, G. lucidum, Hericium erinaceus, and L. edodes fruiting bodies, spores, and cultured broth on cell proliferation and apoptosis in CH72 cancer cells and C50 normal cells were evaluated ( $\mathrm{Gu}$ and Belury, 2005). Out of these extracts, ethanol extract from $L$. edodes significantly inhibited $\mathrm{CH} 72$ cell proliferation, while none of these extracts had effect on normal C50 cells. Cell cycle analysis exhibited that L. edodes extract induced a transient G1 phase arrest in $\mathrm{CH} 72$ cells. Polyozellus multiplex inhibited cell proliferation in stomach cancer by increased expression of $\mathrm{p} 53$ proteins (Lee and Nishikawa, 2003). Lavi et al., (2006) showed that an aqueous polysaccharide extract from the edible mushroom Pleurotus ostreatus induced anti-proliferative and pro-apoptotic effects on HT-29 colon cancer cells. The mushroom extract can be an effective therapy for malignant estrogen-independent breast cancer (Asatiani et al., 2011). Hot-water and ethanol extract of Inonotus obliquus has ability to induce apoptosis in human colon cancer (DLD-1) cells by the prevention of reactive oxygen species (ROS) - induced tissue damage (Hu et al., 2009). Youn et al., (2009) tested the anti-proliferative effects of water extract of I. obliquus extract on B16-F10 cells (murine melanoma). The ethanolic extract of the fruiting body of $P$. igniarius was evaluated as the anti-proliferative and anti-metastatic agent against SK-Hep-1 (human hepatocarcinoma) and RHE (rat heart vascular endothelial). The extract inhibited cell growth of both cell lines in a dose-dependent manner, and the $\mathrm{IC}_{50}$ values at $48 \mathrm{~h}$ were 72 and $103 \mu \mathrm{g} / \mathrm{mL}$ for SK-Hep-1 cells and RHE cells, respectively (Song et al., 2008). The growth of CaSki (Epidermoid cervical carcinoma) cells when treated with the crude dichloromethane extracts of G. lucidum was inhibited (Lai et al., 2010). The dichloromethane extract contains flavonoids, terpenoids, phenolics, and alkaloids with anti-human papillomavirus 16 (HPV 16) E6 oncoprotein activity. The methanol extract and its fractions, viz., methylene chloride, ethyl acetate, and n-butanol of Phellinus linteus exhibited anti-angiogenic effects (Lee et al., 2010). Huang et al., (2011) recorded the anti-cancer effect of P. linteus and interpreted its potential mechanism. They showed increase in number and activity of T cell and NK cell. A. campestris extract inhibited the growth of three cell lines, namely HeLa cells, A549 cells (human lung carcinoma), and LS174 cells (human colon carcinoma) (Kosanić et al., 2017).

In this study, we screened three extracts of $\mathrm{H}$. glabra mushroom (EE, EAE, and WE) against three cervical cancer cell lines, namely HeLa, SiHa, and CaSki by MTT assay. We noted antiproliferation and apoptotic activity of three extract against all three cell lines. In the laboratory (Ghosh, 2015), ME, EE, and WE of wild Calocybe indica were tested for anticancer effect on MCF 7 and Ewing Sarcoma cell line, and similarly antiproliferation and apoptotic effect of ME and EE of Agaricus bisporus against CaSki cell line were reported (Ghosh et al., 2018). EAE of $C$. indica was applied against HeLa and CaSki, and it was found that this extract caused changes in cancer cells and nuclei, apoptosis and inhibited proliferation of these two cell lines and this mushroom extract increased the expression apoptotic genes (caspase 3, 9), tumor guard gene $p 53$ and decreased the pro-apoptotic gene BcL2 (Ghosh et al., 2019). In the present experiment, all mushroom extracts showed morphological changes in all cancer cells and their nuclei, and antiproliferative and apoptotic activity. Increase in concentration of all extracts increased anticancer activity. Antiproliferative effect, including morphological changes, against BXPC3 cell line was also noted (Chen et al., 2009). However, Yu et al., (2012) exhibited that antroquinonol, a ubiquinone derivative isolated from the same mushroom, inhibited cell proliferation of PANC-1 and AsPC-1 cells in dose-dependent manners as we noted in MTT assay. In this study, in three cell lines morphological changes like round and shrunk, and membrane blebbing (bulbing) and the reduction of cell confluence were noted in all extracts. Similar result was found when HeLa cells treated with $500 \mu \mathrm{g} / \mathrm{mL} / 750 \mu \mathrm{g} / \mathrm{mL}$ of methanolic extract of Agaricus bisporus for $24 \mathrm{~h}$ at the same conditions (Ghosh et al., 2018). All extracts also modulated the expression of some genes (Caspase 3, 9, p53, and BcL2). These results were also validated by other researchers investigated other cancer cell lines and other mushrooms (Gu and Belury, 2005; Zaidman et al., 2005). The ethanol and ethyl acetate extracts of Coprinus comatus inhibited LNCaP cells of Prostate cancer (Zaidman et al., 2008). Researchers noted that that these extracts inhibited dihydrotestosteroneinduced LNCaP cell viability and arrested cell cycle at G1 phase. In the cell cycle experiments performed in the present study, EE arrested cell cycle at the G2/M checkpoint of CaSki cells. Similarly, Jiang and Sliva (2010) observed that the methanolic extract of myco-complex induced significant cell cycle arrest at the G2/M phase. Furthermore, cell cycle arrest at G2/M was induced by $A$. blazei in gastric epithelial cells (Jin et al., 2006), and by cordycepin isolated from C. sinensis in bladder cancer cells (Lee et al., 2009).It is noteworthy that different extracts from G. lucidum demonstrated specific effects on cell cycle progression. Extracts from G. lucidum were shown to induce cell cycle arrest at the G0/G1 phase in breast cancer cells (Jiang et al., 2006), where as arrest at the $\mathrm{G} 2 / \mathrm{M}$ phase was induced in prostate (Jiang et al., 2004), hepatoma (Lin et al., 2003) and bladder (Lu et al., 2004) cancer.

The ethyl acetate and culture broth extracts of this also showed antiproliferative activity against MCF7 cells. One study showed that IC50 value was $76 \mu \mathrm{g} / \mathrm{mL}$ for culture broth extract and $32 \mu \mathrm{g} / \mathrm{mL}$ for ethyl acetate extract (Asatiani et al., 2011). Among mushroom extracts, 
an ethanol extract may find the most extensive application. In this study, we also found that EE was the best among three extracts as anticancer agent against three cervical cell lines. On the other hand, we detected that HeLa was more sensitive to EE and EAE, while CaSki cell line was more sensitive to WE than other two. Similar to our findings, one researcher found that ethanol extracts of Pleurotus florida and Calocybe indica caused apoptosis in T24 cell line (Selvi et al., 2011).

In conclusion, all extracts of this mushroom were active in inhibiting the growth of all three cervical cell lines with fair percentage at $24 \mathrm{~h}$. Among three extracts, EE showed maximum anti-proliferation activity against all three cell lines (i.e. HeLa, SiHa, and CaSki). Their activities induced apoptosis and upregulation of apoptotic genes and downregulation of pro-apoptotic genes. In addition, it was detected that EE extract arrested cell cycle at G2/M point. Further studies are suggested to examine the mycochemistry of this mushroom extracts and their application in animal model for next generation anticancer drug development.

\section{Acknowledgements}

Authors are grateful to Principal, RKMVC College, Rahara.

\section{Funding statement}

Authors are grateful to DST, Govt. of West Bengal for funding this research work (Grant no.840 sanc/ ST/P/S\&T/1G-11/2015).

\section{References}

Aly AH, Debbab A, Proksch P (2011). Fifty years of drug discovery from fungi. Fungal Divers, 50, 3-19.

Asatiani MD, Wasser SP, Nevo E, et al (2011). The shaggy Inc cap medicinal mushroom, Coprinus comatus (O.F.Mull.:Fr.) Pers. (Agaricomycetideae) substances interfere with $\mathrm{H} 2 \mathrm{O} 2$ induction of the NF- $\kappa \mathrm{B}$ pathway through inhibition of I $\kappa \mathrm{B} \alpha \mathrm{Phosphorylation} \mathrm{in} \mathrm{MCF7} \mathrm{breast} \mathrm{cancer} \mathrm{cells.} \mathrm{Int} J$ Med Mushrooms, 13, 19-25.

Blackwell M (2011). The Fungi: 1, 2, 3 ... 5.1 million species?. Am J Bot, 98, 426-438.

Brown GD, Gordon S (2003). Fungal $\beta$-glucans and mammalian immunity. Immunity, 19, 311-5.

Chen YJ, Chou CJ, Chang TT (2009). Compound MMH01 possesses toxicity against human leukemia and pancreatic cancer cells. Toxicol In Vitro, 23, 418-24.

Deshmukh SK (2004). Biodiversity of tropical basidiomycetes as sources of novel secondary metabolites. In 'Microbiology and biotechnology for sustainable development', Ed Jain PC. CBS Publishers and Distributors, New Delhi, pp 121-140.

Freshney RI (2015). Culture of animal cells: a manual of basic technique and specialized applications. John Wiley \& Sons.

Ghosh SK (2015). Study of anticancer effect of Calocybe indica mushroom on breast cancer cell line and human Ewings sarcoma cancer cell lines. N Y Sci J, 8, 10-15.

Ghosh SK (2018). Cancer and its remedy by mushrooms. In 'Biotechnology in human Welfare', Ed Chanda and Rakshit. Avenel Press, Kolkata, pp152.

Ghosh SK, Bera T, Pal S (2020). Antiproliferative, apoptotic and antimigration property of ethyl acetate extract of Calocybe indica against $\mathrm{HeLa}$ and CaSki cell lines of cervical cancer, antioxidant and mycochemistry analysis of it. Middle East $J$ Cancer, In Press.

Ghosh SK, Chakrabarty AM (2018). Bioactive compounds of mushrooms as immunoenhancer in human against cancer -an emerging avenue for immunotherapy. In 'Biotechnology and Nature', Eds Dey D et al. Kabitika, Kolkata, pp 233-56.

Ghosh SK, Sanyal T, Chakrabarty AM (2018). Antiproliferative and apoptotic effect of ethanolic and methanolic extract of edible mushroom agaricus bisporus against caski cell Line of cervical cancer. Plant Cell Biotechnol Mol Biol, 19, 372-82.

$\mathrm{Gu}$ YH, Belury MA (2005). Selective induction of apoptosis in murine skin carcinoma cells $(\mathrm{CH} 72)$ by an ethanol extract of Lentinula edodes. Cancer Lett, 220, 21-8.

Hu H, Zhang Z, Lei Z, Yang Y, Sugiura N (2009). Comparative study of antioxidant activity and antiproliferative effect of hot water and ethanol extracts from the mushroom Inonotus obliquus. J Biosci Bioeng, 107, 42-48.

Huang HY, Chieh SY, Tso TK, et al (2011). Orally administered mycelial culture of Phellinus linteus exhibits antitumor effects in hepatoma cell-bearing mice. J Ethnopharmacol, 133, 460-6.

Hunt KK, Vorburger SA (2002). Hurdles and hopes for cancer treatment. Science, 297, 415-6.

ICO Information Centre on HPV and cancer (2014). Human Papilloma virus and Related Diseases in India (Summary Report 2014-08-22).

Jiang J, Sliva D (2010). Novel medicinal mushroom blend suppresses growth and invasiveness of human breast cancer cells. In J Oncol, 37, 1529-36.

Jiang J, Slivova V Sliva D (2006). Ganoderma lucidum inhibits proliferation of human breast cancer cells by down-regulation of estrogen receptor and NF-kappa B signaling. Int J Oncol, 29, 695-703.

Jiang J, Slivova V, Harvey K, Valachovicova T, Sliva D (2004). Ganoderma lucidum suppresses growth of breast cancer cells through the inhibition of Akt/NF-kappaB signaling. Nutr Can, 49, 209-16.

Jiang MY, Li Y, Wang F, Liu JK (2011). Isoprenylated cyclohexanoidsfrom the basidiomyceteHexagonia speciosa. Phytochemistry, 72, 923-8.

Jiang MY, Zhang L, Liu R, Dong ZJ, Liu JK (2009). Speciosins A-K,oxygenated cyclohexanoids from the basidiomycete Hexagonia speciosa. J Nat Prod, 72, 1405-9.

Jin CY, Choi YH, Moon DO (2006). Induction of G2/M arrest and apoptosis in human gastric epithelial AGS cells by aqueous extract of Agaricus blazei. Oncol Rep, 16, 1349-55.

Kim HM, Han SB, Oh GT, et al (1996). Stimulation of humoral and cell mediated immunity by polysaccharide from mushroom Phellinus linteus. Int J Immunopharmacol, 18, 295-303.

Kosanić M, Ranković B, Stanojković T (2017). Bioactivity of edible mushroom Agaricus campestris. Zbornik radova, Knjiga, 2, 579-84.

Kurashige S, Akuzawa Y, Endo F (1997). Effects of Lentinus edodes, Grifola frondosa and Pleurotus ostreatus administration on cancer outbreak, and activities of macrophages and lymphocytes in mice treated with a carcinogen, N-butyl-N-butanolnitrosoamine. Immunopharmacol Immunotoxicol, 19, 175-83.

Ladanyi A, Timar J, Lapis K (1993). Effect of lentinan on macrophage cytotoxicity against metastatic tumor cells. Cancer Immunol Immunother, 36, 123-6.

Lai LK, Abidin NZ,Abdullah N, Sabaratnam V(2010). Anti-human papillomavirus (HPV) 16 E6 activity of Ling Zhi or Reishi medicinal mushroom, Ganoderma lucidum (W. Curt.: Fr.) P. Karst.(Aphyllophoromycetideae) extracts. Int $J$ Med Mushrooms, 12, 279-86. 
Lavi I, Friesem D, Geresh S, Hadar Y, Schwartz B (2006). An aqueous polysaccharide extract from the edible mushroom Pleurotus ostreatus induces anti-proliferative and pro-apoptotic effects on HT-29 colon cancer cells. Cancer Lett, 244, 61-70.

Lee IS, Nishikawa A (2003). Polyozellus multiplex, a Korean wild mushroom, as a potent chemopreventive agent against stomach cancer. Life Sci, 73, 3225-34.

Lee S, Lee Y, Choi YJ, Han K-S, Chung HW (2014). Cyto-/genotoxic effects of the ethanol extract of Chan $\mathrm{Su}$, a traditional Chinese medicine, in human cancer cell lines. J Ethnopharmacol, 152, 372-6.

Lee SJ, Kim SK, Choi WS, Kim WJ, Moon SK (2009). Cordycepin causes p21WAF1-mediated G2/M cell-cycle arrest by regulating c-Jun $\mathrm{N}$-terminal kinase activation in human bladder cancer cells. Arch Biochem Biophys, 490, 103-9.

Lee YS, Kim YH, Shin EK, et al (2010). Anti-angiogenic activity of methanol extract of Phellinus linteus and its fractions. J Ethnopharmacol, 131, 56-62.

Lin SB, Li CH, Lee SS, Kan LS (2003). Triterpene-enriched extracts from Ganoderma lucidum inhibit growth of hepatoma cells via suppressing protein kinase $C$, activating mitogen-activated protein kinases and G2-phase cell cycle arrest. Life Sci, 72, 2381-90.

Lindequist U, Rausch R, Füssel A, Hanssen HP (2010). Higher fungi in traditional and modern medicine. Med Monatsschr Pharm, 33, 40-8.

Liu J, Shimizu K, Kondo R (2010). The effects of ganoderma alcohols isolated from Ganoderma lucidum on the androgen receptor binding and the growth of LNCaP cells. Fitoterapia, 81, 1067-72.

Lu QY, Jin YS, Zhang Q, et al (2004). Ganoderma lucidum extracts inhibit growth and induce actin polymerization in bladder cancer cells in vitro. Cancer Lett, 216, 9-20.

Lucas EH, Ringler RL, Byerrum RU, et al (1957). Tumor inhibitors in Boletus edulis and other Holobasidiomycetes. Antibiot Chemother, 7, 1-14.

Manoharachary C, Sridhar K, Singh R, et al (2005). Fungal biodiversity: distribution, conservation and prospecting of fungi from India. Curr Sci, 89, 58-71.

Mizuno T (1995). Bioactive biomolecules of mushrooms: Food function and medicinal effect of mushroom fungi. Food Rev Int, 11, 7-21.

Mizuno T (1999). The extraction and development of antitumoractive polysaccharides from medicinal mushrooms in Japan. Int J Med Mushrooms, 1, 9-29.

Mo S (2004). Cytotoxic pyrano [4, 3-c][2] benzopyran-1, 6-dione and furo $[3,2-c]$ pyran-4-one derivatives from the fungus Phellinus igniarius. J Nat Prod, 67, 823-8.

Moradali MF, Mostafavi H, Ghods S, Hedjaroude GA (2007). Immunomodulating and anticancer agents in the realm of macro- mycetes fungi (macrofungi). Int Immunopharmacol, 7, 701-24.

Moser M (1983). Die Röhrlinge, \& Blätterpilze (Polyporales, Boletales, Agaricales, Russulales). In 'Kleine Kryptogamenflora, Band II b/2. Basidiomyceten, 2. Teil, 5', Ed Gams H. Aufl. Gustav Fischer Verlag, Stuttgart, pp 1-532

Mosmann T (1983). Rapid colorimetric assay for cellular growth and survival: application to proliferation and cytotoxicity assays. J Immunol Methods, 65, 55-63.

Pacioni G, Lincoff GH (1981). Simon \& Schuster's guide to mushrooms. Simon and Schuster.

Poucheret P, Fons F, Rapior S (2006). Biological and pharmacological activity of higher fungi: 20-year retrospective analysis. Mycologie, 27, 311-33.

Prestwich RJ, Errington F, Hatfield P, et al (2008). The immune system-is it relevant to cancer development, progression and treatment?. Clin Oncol, 20, 101-12.

Ryvarden L (1999). Type studies in the Polyporaceae. 26. Species described by A.M.F. Palisot de Beauvois. Mycotaxon, 72, 215-216.

Selvi S, Umadevi P, Murugan S, Senapathy JG (2011). Anticancer potential evoked by Pleurotus florida and Calocybe indica using T 24 urinary bladder cancer cell line. Afr J Biotechnol, 10, 7279-85.

Shavit E, Rose D, French A, et al (2009). Over-the-counter medicinal mushrooms. Fungi, 2, 15-9.

Silva FS, de Sá MS, Costa JF, et al (2009). In vitro pharmacological screening of macrofungi extracts from the Brazilian northeastern region. Pharm Biol, 47, 384-9.

Song TY, Lin HC, Yang NC, Hu ML (2008). Antiproliferative and antimetastatic effects of the ethanolic extract of Phellinus igniarius (Linnearus: Fries) Quelet. J Ethnopharmacol, 115, 50-56.

Sreedevi A, Javed R, Dinesh A (2015). Epidemiology of cervical cancer with special focus on India. Int $J$ Womens Health, 7, 405-14.

Vorauer K, Steindl F, Jungbauer A, Hahn R, Katinger H (1996). Cytokine activity assay by means of proliferation measured in plane convex microtiter wells. J Biochem Biophys Methods, 32, 85-96.

Wasser S (2002). Medicinal mushrooms as a source of antitumor and immunomodulating polysaccharides. App Microbiol Biotechnol, 60, 258-74.

Wasser SP (2011). Current findings, future trends, and unsolved problems in studies of medicinal mushrooms. Appl Microbiol Biotechnol, 89, 1323-32.

Watling R (1973). Identification of the larger fungi. Hulton Educational Publications Ltd.

Xu X, Yan H, Chen J, Zhang X (2011). Bioactive proteins from mushrooms. Biotechnol Adv, 29, 667-74.

Youn MJ, Kim JK, Park SY, et al (2009). Potential anticancer properties of the water extract of Inontus obliquus by induction of apoptosis in melanoma B16-F10 cells. J Ethnopharmacol, 121, 221-8.

Younis AM, Yosri M, Stewart JK (2019). In vitro evaluation of pleiotropic properties of wild mushroom Laetiporus sulphureus. Ann Agric Sci, 64, 79-87.

Yu CC, Chiang PC, Lu PH, et al (2012). Antroquinonol, a natural ubiquinone derivative, induces a cross talk between apoptosis, autophagy and senescence in human pancreatic carcinoma cells. J Nutr Biochem, 23, 900-7.

Zaidman BZ, Wasser SP, Nevo E, Mahajna J (2008). Coprinus comatus and Ganoderma lucidum interfere with androgen receptor function in LNCaP prostate cancer cells. Mol Biol Rep, 35, 107-17.

Zaidman BZ, Yassin M, Mahajna J, Wasser SP (2005). Medicinal mushroom modulators of molecular targets as cancer therapeutics. Appl Microbiol Biotechnol, 67, 453-68.

Zhao JD (1998). Flora Fungorum sinicorum. Polyporaceae. Vol. 3. Science Press, Beijing, pp 186-7.

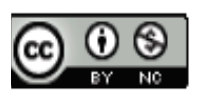

This work is licensed under a Creative Commons AttributionNon Commercial 4.0 International License. 